\title{
Evaluation of the usefulness of molecular markers Xgwm205, Xcfd81, Whs350 for the identification of resistance gene Pm2 to powdery mildew (Blumeria graminis f. sp. tritici) in wheat cultivars of different origins
}

\author{
Ocena przydatności markerów molekularnych Xgwm205, Xcfd81, Whs350 \\ do identyfikacji genu odporności Pm2 na mączniaka prawdziwego zbóż \\ i traw (Blumeria graminis f. sp. tritici) u odmian pszenicy \\ o zróżnicowanym pochodzeniu
}

Agnieszka Tomkowiak ${ }^{1 *}$, Danuta Kurasiak-Popowska ${ }^{1}$, Joanna Grynia ${ }^{2}$, Jerzy Nawracała ${ }^{1}$, Sylwia Mikołajczyk ${ }^{1}$, Dorota Weigt ${ }^{1}$, Janetta Niemann ${ }^{1}$, Angelika Kiel $^{1}$

\begin{abstract}
Summary
The most efficient, cost effective, and safe method of controlling and limiting the presence of pathogen is cultivation of resistant varieties of wheat. The development of disease-resistant varieties is very important because pathogens often develop and form new races or strains. Those varieties accumulate few types of gene resistant to a particular disease. Pyramiding host-plant resistance genes is one of the most effective approaches in plant breeding. The aim of the research was to evaluate the usefulness of molecular markers: Xgwm205, Xcfd81 and Whs350 in identifying the resistance of the Pm2 to powdery mildew in 27 varieties of wheat of different origins. The collection of these varieties belongs to the Department of Genetics and Plant Breeding, University of Life Sciences in Poznan. The analyses of the SSR-PCR revealed that the Xgwm205 was the most effective marker used to identify the Pm2 gene and it appeared in 25 out of 27 analyzed varieties of wheat. The Xcfd81 identified the gene in 21 varieties of wheat and resulted in an amplification measuring $283 \mathrm{bp}$. The Whs350 was the weakest in identifying the Pm2 gene. It resulted in a product measuring $598 \mathrm{bp}$, which appeared in only 9 of the analyzed varieties. Based on the conducted analysis, the Xgwm205 and Xcfd81 molecular markers are the most accurate in identifying the $P m 2$ gene.
\end{abstract}

Key words: wheat; breeding; resistance; molecular markers

\section{Streszczenie}

Najbardziej skuteczną, ekonomiczną i bezpieczną metodą kontrolowania i ograniczenia występowania patogena jest uprawianie odmian odpornych. Przełamywanie odporności przez nowe rasy patogenów jest powodem hodowli nowych odmian, w których próbuje się zgromadzić kilka genów odporności na daną chorobę. Piramidyzacja genów jest możliwa dzięki wykorzystaniu funkcjonalnych markerów molekularnych do bezpośredniej identyfikacji genów. Celem badań była ocena przydatności markerów molekularnych Xgwm205, Xcfd81 oraz Whs350 do identyfikacji genu odporności Pm2 na mączniaka prawdziwego zbóż i traw u 27 odmian pszenicy zwyczajnej o zróżnicowanym pochodzeniu, znajdujących się w kolekcji Katedry Genetyki i Hodowli Roślin Uniwersytetu Przyrodniczego w Poznaniu. W wyniku analiz SSR-PCR stwierdzono, że najbardziej skutecznym markerem do identyfikacji genu Pm2 był marker Xgwm205 dający produkt o długości 143 pz, który pojawił się u 25 z 27 analizowanych odmian pszenicy. Marker Xcfd81 dający produkt amplifikacji o długości 283 pz zidentyfikował gen Pm2 u 21 odmian. Markerem najsłabiej identyfikującym gen Pm2 w badanej kolekcji odmian był Whs350 dający produkt o długości 598 pz, który pojawił się tylko u 9 analizowanych odmian. Na podstawie przeprowadzonych analiz do identyfikacji genu Pm2 zaleca się markery molekularne Xgwm205 oraz Xcfd81.

Słowa kluczowe: pszenica; hodowla; odporność; markery molekularne

\footnotetext{
'Uniwersytet Przyrodniczy w Poznaniu, Wojska Polskiego 28, 60-632 Poznan

${ }^{2}$ Hodowla Roślin Strzelce Sp. z o.o. Grupa IHAR, Główna 20, 99-307 Strzelce

*corresponding author: agatom@up.poznan.pl
} 


\section{Wstęp / Introduction}

Obok rdzy brunatnej i rdzy żółtej mączniak prawdziwy zbóż i traw jest jedną z groźniejszych chorób grzybowych powodujących duże straty w plonach zbóż na świecie (Parks i wsp. 2008; Walker i wsp. 2011; Klocke i wsp. 2013). Straty te mogą sięgać nawet $50 \%$ w przypadku pszenicy oraz 15\% w pszenżycie (Czembor i wsp. 2013; Mwale i wsp. 2014). Obecnie hodowla odpornych odmian roślin uprawnych jest uznawana za najlepszą i najbardziej ekonomiczną metodę walki z chorobami i szkodnikami, ponieważ intensywna chemiczna ochrona roślin nie pozostaje obojętna dla środowiska i budzi coraz większy sprzeciw konsumentów. Uprawa odmian odpornych, w tym również na mączniaka prawdziwego zbóż i traw (Blumeria graminis f. sp. tritici) pozwala w sposób skuteczny i bezpieczny zmniejszyć ilość stosowanych fungicydów przy jednoczesnym wzroście jakości i ilości plonu. Szczególnie przydatną metodą w hodowli odpornościowej jest selekcja przy użyciu markerów molekularnych MAS (Marker-Assisted Selection), która pozwala na wykrycie obecności określonych genów lub QTL (Quantitative Trait Loci) w roślinach. Obecnie poznano 41 genów Pm odporności na mączniaka prawdziwego zbóż i traw pochodzących z pszenicy i 8 genów Pm z żyta (McIntosh i wsp. 2013).

Celem badań była ocena przydatności markerów molekularnych Xgwm205, Xcfd81, Whs350 do identyfikacji genu odporności $P m 2$ na mączniaka prawdziwego zbóż i traw u odmian pszenicy zwyczajnej o zróżnicowanym pochodzeniu.

\section{Materiały i metody / Materials and methods}

Materiałem roślinnym użytym do badań było 27 odmian pszenicy zwyczajnej o zróżnicowanym pochodzeniu (tab. 1). Jak wynika z informacji z banku genów National Small Grains Collection znajdującego się w Agriculture Research Station (Aberdeen) odmiany te charakteryzują się dobrą odpornością na mączniaka prawdziwego zbóż i traw oraz zawierają geny Pm2. Odmiany te wchodzą w skład kolekcji pszenicy zwyczajnej zgromadzonej w Katedrze Genetyki i Hodowli Roślin Uniwersytetu Przyrodniczego w Poznaniu.

Materiał do badań pobrano z 10-dniowych siewek uzyskanych ze skiełkowanych w warunkach laboratoryjnych ziarniaków. Z każdej odmiany, z losowo wybranych 5 roślin pobrano fragment liścia do izolacji. Izolację DNA prowadzono wykorzystując zestaw do izolacji DNA $\mathrm{z}$ roślin Genomic Mini AX PLANT firmy A\&A BIOTECHNOLOGY zgodnie $\mathrm{z}$ dołączoną procedurą. Próby po izolacji rozcieńczano wodą destylowaną w celu uzyskania jednolitego stężenia DNA $40 \mathrm{ng} / \mu \mathrm{l}$. Stężenia sprawdzano przy użyciu fluorymetru NanoDrop. Reakcję PCR (Polymerase Chain Reaction) przeprowadzono w mieszaninie o składzie: woda - $5 \mu \mathrm{l}$, DreamTaq ${ }^{\mathrm{TM}}$ Green PCR Master Mix $-6,25 \mu \mathrm{l}$, startery $-2 \times 0,25 \mu \mathrm{l}$ (stężenie końcowe starterów wynosiło $20 \mu \mathrm{M}$ ), matryca DNA - $1 \mu \mathrm{l}$. W celu stwierdzenia obecności genu Pm2 w odmianach wykorzystano trzy specyficzne markery: Xgwm205, Xcfd81, Whs350, do identyfikacji których użyto trzech par starterów. Sekwencje starterów pochodzą z bazy danych Grain Genes (https://wheat.pw.usda.gov/):

Tabela 1. Lista badanych odmian oraz wykaz hodowców, bądź reprezentantów (pełnomocników)

Table 1. List of studied cultivars and the list of breeders or representatives

\begin{tabular}{c|l|l|l|l|l}
\hline \multicolumn{2}{c|}{$\begin{array}{l}\text { Odmiana } \\
\text { Cultivar }\end{array}$} & \multicolumn{1}{|c|}{$\begin{array}{c}\text { Hodowca/reprezentant } \\
\text { Breeder/representative }\end{array}$} & \multicolumn{2}{|c}{$\begin{array}{l}\text { Odmiana } \\
\text { Cultivar }\end{array}$} & \multicolumn{1}{c}{$\begin{array}{l}\text { Hodowca/reprezentant } \\
\text { Breeder/representative }\end{array}$} \\
\hline 1 & Agra & KCRZG IHAR PL & $\begin{array}{l}\text { Maris } \\
\text { Huntsman* }\end{array}$ & RAGT Seeds Ltd UK \\
\hline 2 & Almari* & $\begin{array}{l}\text { Hodowla Roślin Smolice Sp. z o.o. Grupa } \\
\text { IHAR PL }\end{array}$ & 16 & Meister* & RAGT FR \\
\hline 3 & Atomic* & Limagrain Advanta Nederland BV NL & 17 & Novalis* & $\begin{array}{l}\text { Deutsche Saatveredelung Lippstadt-Bremen GmbH } \\
\text { zu Lippstadt DE }\end{array}$ \\
\hline 4 & Bussard* & KWS Lochow GMBH DE & 18 & Planet & KCRZG IHAR PL \\
\hline 6 & Clever* & $\begin{array}{l}\text { Saatenvertrieb Nord Erhardt Eger OHG } \\
\text { DE }\end{array}$ & 19 & Primus* & $\begin{array}{l}\text { Deutsche Saatveredlung Lippstadt-Bremen GmbH } \\
\text { zu Lippstadt DE }\end{array}$ \\
\hline 7 & Florian* & Nordsaat GmbH DE & 20 & Sparta & BGCz CSK \\
\hline 8 & Hondia* & Danko Hodowla Roślin Sp. z o.o. PL & 22 & Tobak* & BGCz CSK \\
\hline 9 & Impression* & Saatzucht Schweiger GbR DE & 23 & Tonacja* & Hodowla Roślin Strzelce Sp. z o.o. Grupa IHAR PL \\
\hline 10 & Juma & KCRZG IHAR PL & 24 & Torysa* & Semillas Battle SA ES \\
\hline 11 & Kamila* & $\begin{array}{l}\text { Małopolska Hodowla Roślin-HBP } \\
\text { Sp. z o.o. PL }\end{array}$ & 25 & Ulka & BGCz CSK \\
\hline 12 & Kobra* & $\begin{array}{l}\text { Małopolska Hodowla Roślin-HBP } \\
\text { Sp. z o.o. PL }\end{array}$ & 26 & Wydma* & Hodowla Roślin Smolice Sp. z o.o. Grupa IHAR PL \\
\hline 13 & Lama & KCRZG IHAR PL & 27 & Zorza* & Małopolska Hodowla Roślin-HBP Sp. z o.o. PL \\
\hline 14 & Lear* & Limagrain GmbH DE & - & - \\
\hline
\end{tabular}

*baza odmian roślin - plant cultivar database - European Commission

(http:/ec.europa.eu/food/plant/plant_propagation_material/plant_variety_catalogues_databases) 


\section{Xgwm205 - F:5’CGACCCGGTTCACTTCAG3’, R:5’AGTCGCCGTTGTATAGTGCC3’ \\ Xcfd81 - F:5’TATCCCCAATCCCCTCTT3', R:5’GTCAATTGTGGCTTGTCCCT3’ \\ Whs350 - F:5’AGCTGTTTGGGTACAAGGTG3', R:5’TCCCCTGTGCTACTACTTCTC3’.}

Po zoptymalizowaniu reakcję PCR przeprowadzono w termocyklerze TProfesional Basic z firmy POLYGEN w tych samych warunkach niezależnie od identyfikowanego markera, profil różnił się tylko temperaturą przyłączania starterów ustaloną zgodnie z temperaturą ich topnienia: denaturacja wstępna -3 min. w $94^{\circ} \mathrm{C}, 40$ cykli (denaturacja - $30 \mathrm{~s} \mathrm{w} 94^{\circ} \mathrm{C}$, przyłączanie starterów - 1 min. w $54^{\circ} \mathrm{C}, 58^{\circ} \mathrm{C}, 63^{\circ} \mathrm{C}$, synteza -1 min. w $72^{\circ} \mathrm{C}$ ), synteza końcowa -5 min. $\mathrm{w} 72^{\circ} \mathrm{C}$, przechowywanie max. $24 \mathrm{~h}$ $\mathrm{w} 4^{\circ} \mathrm{C}$. Elektroforezę prowadzono w $2,5 \%$ żelu agarozowym zanurzonym w buforze TBE $1 \mathrm{x}$ przy użyciu prądu o napięciu $100 \mathrm{~V}$ i natężeniu $200 \mathrm{~mA}$. Do wizualizacji wyników wykorzystano transiluminator Molecular Imager Gel Doc ${ }^{\mathrm{TM}}$ XR oraz ImageLab ${ }^{\mathrm{TM}}$ Software firmy Biorad.

\section{Wyniki i dyskusja / Results and discussion}

W wyniku przeprowadzonych analiz PCR-SSR z wykorzystaniem markera Xgwm205 sprzężonego z genem
Pm2 zidentyfikowano specyficzny produkt amplifikacji o długości 143 pz u 25 spośród 27 analizowanych odmian (rys. 1, 2). Marker ten nie pojawił się w przypadku odmian Impression i Planet (rys. 2). Analizując obrazy elektroforetyczne po reakcji PCR-SSR, w której wykorzystano startery identyfikujące marker $X c f d 81$, specyficzny produkt o długości $283 \mathrm{pz}$ pojawił się w 21 analizowanych genotypach (rys. 3, 4). Markera nie zaobserwowano u następujących odmian: Lama, Maris Huntsman i Kamila (rys. 3) oraz Meister, Finezja i Impression (rys. 4). Jako trzeci marker sprzężony z genem Pm2 testowano Whs350 dający produkt o długości $598 \mathrm{pz}$. W wyniku przeprowadzonych analiz marker ten zaobserwowano tylko w 9 spośród 27 genotypów (rys. 5, 6). Produkt o długości 598 pz pojawił się u odmian: Maris Huntsman, Bussard i Sparta (rys. 5) oraz Meister, Impression, Atomic, Ulka, Tonacja i Lear (rys. 6). Jak przedstawiono na załączonych elektroforogramach u wszystkich analizowanych odmian pojawił się przynajmniej 1 z 3 analizowanych markerów sprzężonych z genem Pm2.

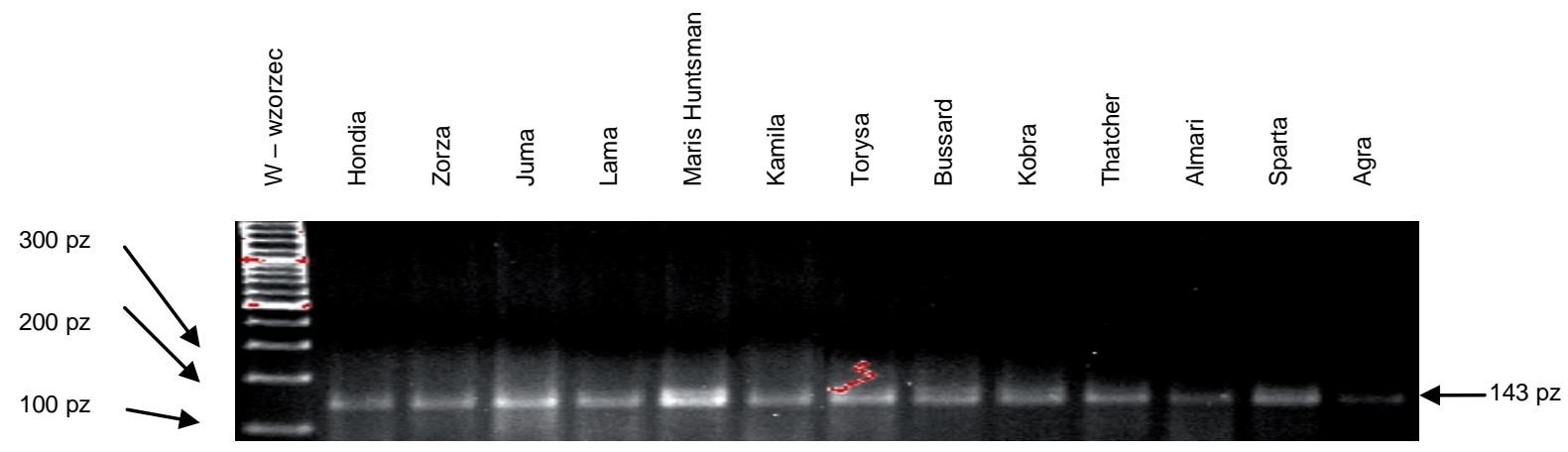

W - wzorzec - standard, pz - bp

Rys. 1. Elektroforogram przedstawiający występowanie markera Xgwm205 genu Pm2 u odmian pszenicy

Fig. 1. Agarose gel electrophoresis showing the presence of a marker Xgwm205 of gene Pm2 in wheat cultivars

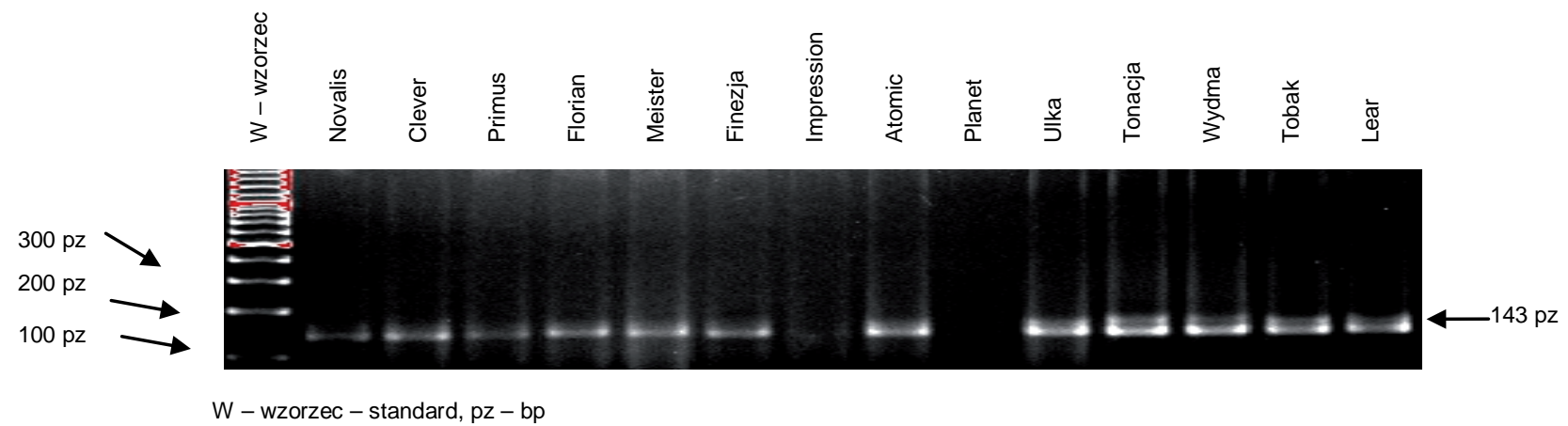

Rys. 2. Elektroforogram przedstawiający występowanie markera Xgwm205 genu Pm2 u odmian pszenicy

Fig. 2. Agarose gel electrophoresis showing the presence of a marker Xgwm205 of gene Pm2 in wheat cultivars 


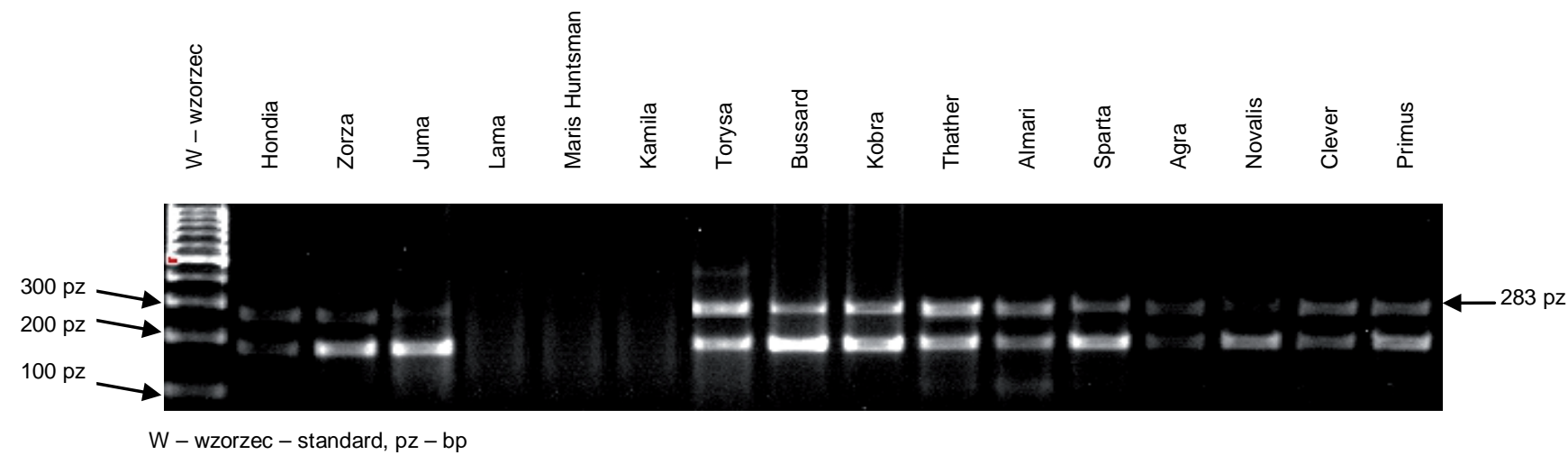

Rys. 3. Elektroforogram przedstawiający występowanie markera Xcfd81 genu Pm2 u odmian pszenicy

Fig. 3. Agarose gel electrophoresis showing the presence of a marker Xcfd81 of gene Pm2 in wheat cultivars

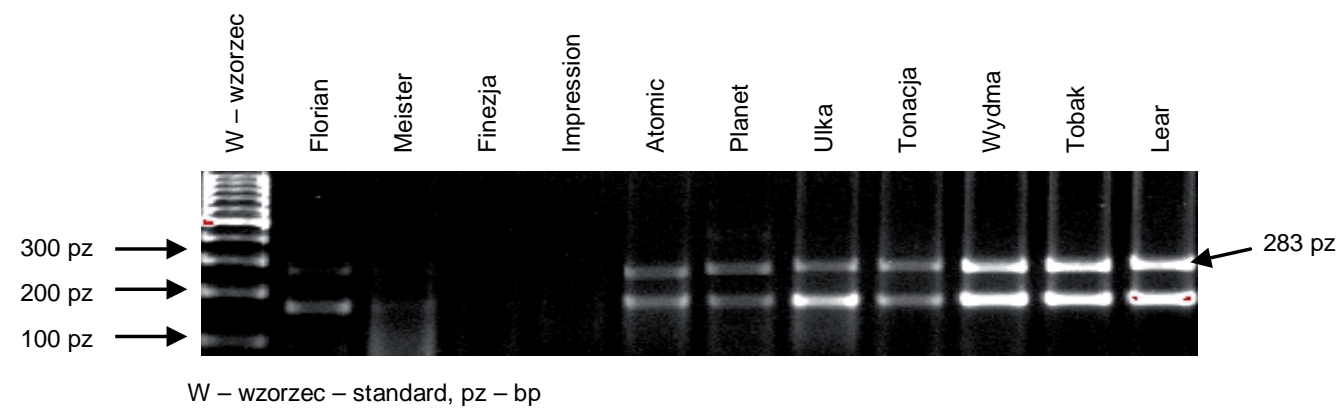

Rys. 4. Elektroforogram przedstawiający występowanie markera $X c f d 81$ genu $P m 2$ u odmian pszenicy

Fig. 4. Agarose gel electrophoresis showing the presence of a marker $X c f d 81$ of gene $P m 2$ in wheat cultivars

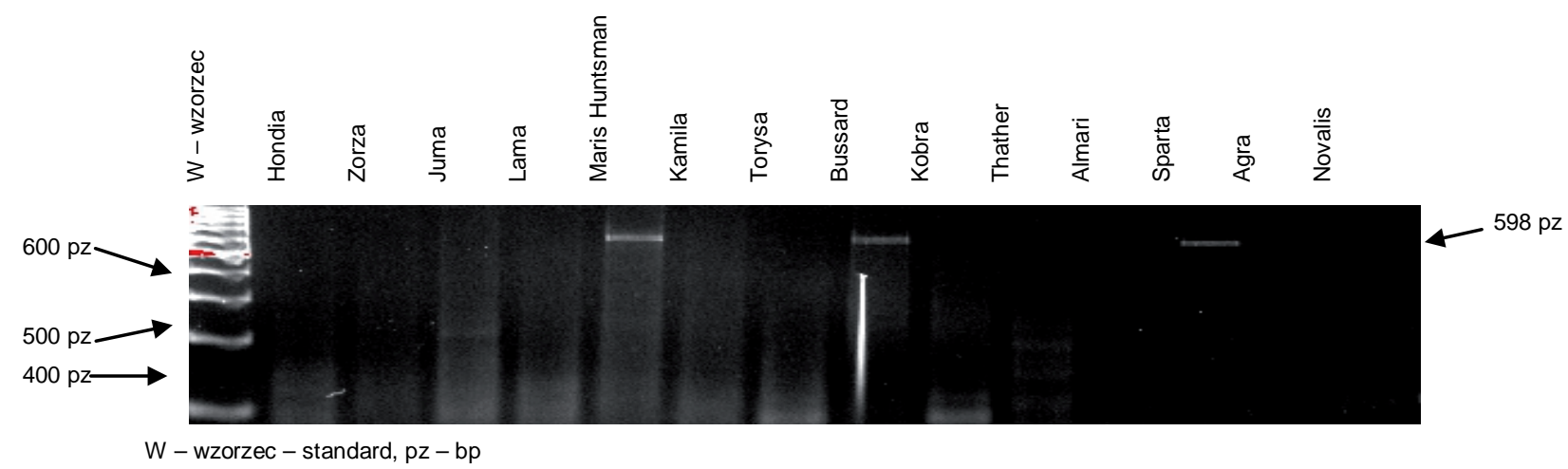

Rys. 5. Elektroforogram przedstawiający występowanie markera Whs350 genu Pm2 u odmian pszenicy

Fig. 5. Agarose gel electrophoresis showing the presence of a marker Whs350 of gene Pm2 in wheat cultivar

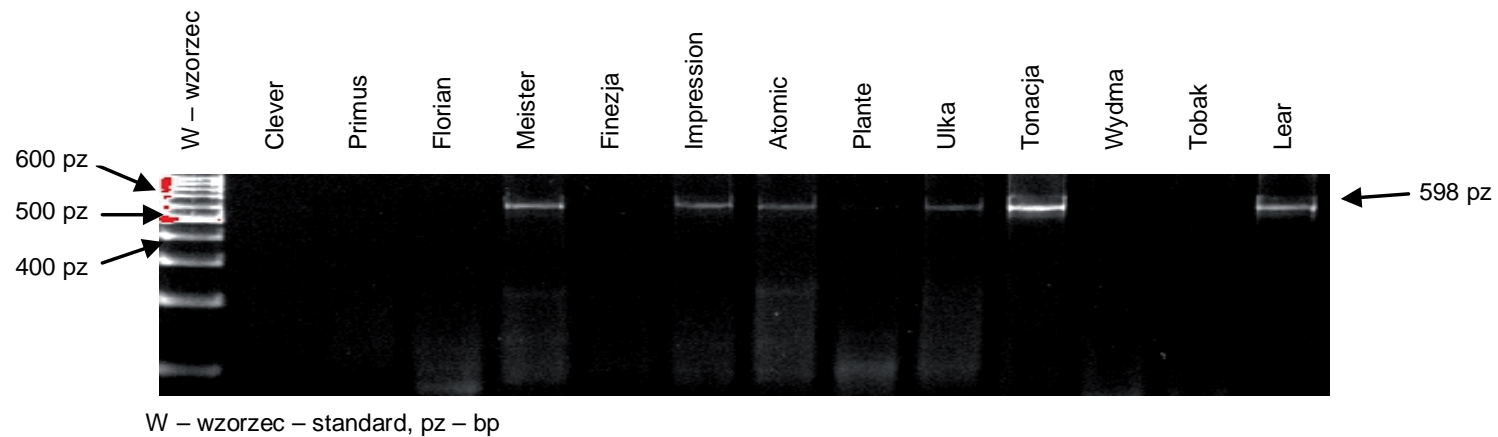

Rys. 6. Elektroforogram przedstawiający występowanie markera Whs350 genu Pm2 u odmian pszenicy

Fig. 6. Agarose gel electrophoresis showing the presence of a marker Whs 350 of gene Pm2 in wheat cultivars 
Kluczowym czynnikiem wpływającym na plon nie tylko pszenicy, ale wszystkich roślin jest porażenie przez patogeny. Jedną z najczęściej pojawiających się chorób pszenicy zwyczajnej o znaczeniu ekonomicznym obok rdzy brunatnej i żółtej jest mączniak prawdziwy zbóż i traw (B. graminis f. sp. tritici). Obecnie najbardziej skuteczną i bezpieczną metodą ochrony roślin przed patogenami jest uprawa odmian odpornych. Dzięki wprowadzeniu do genomu pszenicy genów odporności na mączniaka prawdziwego zbóż i traw, można zapobiec rozprzestrzenianiu się choroby, a tym samym ustabilizować plon. Odporność na mączniaka prawdziwego zbóż i traw warunkowana jest pojedynczym genem $R$. Pojedyncza mutacja w genie Avr patogena powodująca zmianę tego genu często prowadzi do przełamania monogenicznej odporności rośliny. W tej sytuacji dąży się do piramidyzacji genów, aby zapewnić im jak najlepszą ochronę przed patogenami (McDonald i Linde 2002). Jednym $\mathrm{z}$ powszechnie wykorzystywanych $\mathrm{w}$ piramidyzacji genów odporności na mączniaka prawdziwego zbóż i traw jest gen Pm2 (Alam i wsp. 2011).

Gen odporności na mączniaka prawdziwego zbóż i traw Pm2 jest szeroko wykorzystywany i występuje w wielu odmianach pszenicy (Bennett 1984; Lutz i wsp. 1992, 1995; Paderina i wsp. 1995; Huang i wsp. 1997). Odporność warunkowana genem Pm2 nie jest skuteczna w stu procentach $\mathrm{z}$ uwagi na obecność wirulencji w wielu obszarach geograficznych (Persaud i Lipps 1995; Niewoehner i Leath 1998; Duan i wsp. 2002; Parks i wsp. 2008). Mimo, że genu tego nie można traktować jako głównego czynnika odporności u roślin może on okazać się bardzo użyteczny $\mathrm{w}$ połączeniu $\mathrm{z}$ innymi genami odporności na mączniaka prawdziwego zbóż i traw (Ma i wsp. 2011).

W polskich odmianach pszenic ozimych i jarych najczęściej spotyka się następujące kombinacje genów odporności na mączniaka prawdziwego zbóż i traw: Pm2 + Pm5, Pm2 + Pm6, Pm3d + Pm8, Pm3d + Pm nieokreślony, $P m 5+P m 8, P m 1+P m 2+P m$ nieokreślony, $P m 1+$ $P m 3 d+P m 4 b, P m 2+P m 3 d+P m 4 b, P m 2+P m 6+P m$ nieokreślony, $P m 3 d+P m 4 b+P m$ nieokreślony oraz $P m 1$ $+P m 2+P m 9+P m 4 b$ (Pietrusińska 2010). Istnieje wiele przykładów wprowadzania efektywnych genów odporności do jednego genotypu. Liu i wsp. (2000) wprowadzili dwa geny odporności na mączniaka prawdziwego zbóż i traw w kombinacjach: Pm4a + Pm21 oraz Pm2 + Pm21 do chińskiej odmiany pszenicy Yang158. Obecnie próbuje się piramidyzować geny odporności na różne patogeny. Pietrusińska (2010) wykorzystując selekcję wspomaganą markerami molekularnymi wprowadziła do odmiany Lexus gen odporności na rdzę brunatną Lr41 oraz gen odporności na mączniaka prawdziwego zbóż i traw Pm21.

W pracy oceniano przydatność markerów molekularnych Xgwm205, Xcfd81, Whs350 do identyfikacji genu odporności Pm2 na mączniaka prawdziwego zbóż i traw u 27 odmian pszenicy zwyczajnej o zróżnicowanym pochodzeniu. W wyniku analiz SSR-PCR stwierdzono, że najbardziej skutecznym markerem do identyfikacji genu Pm2 jest marker Xgwm205 dający produkt o długości 143 pz, który pojawił się u 25 z 27 analizowanych odmian pszenicy. Drugim, co do skuteczności identyfikacji genu
Pm2, testowanym w pracy markerem okazał się Xcfd81 dający produkt amplifikacji o długości 283 pz u 21 odmian. Jak wynika $\mathrm{z}$ najnowszych badań prowadzonych przez Ma i wsp. (2015a, b, c) zarówno marker Xgwm205, jak i Xcfd81 okazały się skutecznymi wskaźnikami świadczącymi o obecności genu Pm2 w analizowanych genotypach. W pracy Gao i wsp. (2012) autorzy wykazali, że markery Xgwm205 i Xcfd81 są sprzężone również z genem Pm46. Początkowo sądzono, że geny zidentyfikowane w odpornych na mączniaka prawdziwego zbóż i traw odmianach Tabasco i Ulka są różnymi formami allelicznymi genu Pm2. W toku analiz udowodniono, że gen Pm46 w odmianie Tabasco różni się od genu $P m 2$ w odmianie Ulka.

Mimo, iż w niektórych krajach doszło do przełamania odporności na mączniaka prawdziwego zbóż i traw niesionej przez gen Pm2 cały czas prowadzone są prace związane $\mathrm{z}$ tym genem czego dowodem jest praca Ma i wsp. (2016), którzy wykorzystując markery specyficzne oraz markery SNP zidentyfikowali nową formę alleliczną $P m F G$ genu Pm2 w mieszańcach pochodzących $\mathrm{z}$ przekrzyżowania bardzo odpornej zarówno w stadium siewki, jak i rośliny dorosłej francuskiej linii FG-1 z genotypem Mingxian169.

Najmniej specyficznym markerem identyfikującym gen Pm2 w badanej kolekcji odmian jest Whs350 dający produkt o długości 598 pz, który pojawił się u 9 analizowanych odmian. Z uwagi na słabą specyficzność jest on najrzadziej opisywany $\mathrm{w}$ najnowszej literaturze spośród testowanych markerów.

W toku analiz wytypowano 6 odmian, u których udało się zidentyfikować trzy testowane markery sprzężone $\mathrm{z}$ genem Pm2. Należą do nich: Bussard, Sparta, Atomic, Ulka, Tonacja i Lear. Odmiany te można traktować jako referencyjne stanowiące pewne źródło genów odporności na mączniaka prawdziwego zbóż i traw Pm2.

W ostatnich 10 latach odkryto i zmapowano wiele skutecznych genów odporności na mączniaka prawdziwego zbóż i traw. Są to na przykład: Pm34 (Miranda i wsp. 2006), Pm35 (Miranda i wsp. 2007), PmY39 (Zhu i wsp. 2006), PmY201 i PmY212 (Sun i wsp. 2006), Mlm2033, Mlm80 i Pm2026 (Yao i wsp. 2007; Xue i wsp. 2008), PmLK906 (Niu i wsp. 2008) oraz Pm43 (He i wsp. 2009).

Kumulacja różnych kombinacji genów warunkujących odporność na ważne z punktu widzenia rolniczego choroby jest metodą powszechnie stosowaną w programach hodowlanych na całym świecie.

\section{Wnioski / Conclusions}

1. Wykazano przydatność markerów molekularnych Xgwm205 oraz Xcfd81 do identyfikacji genu Pm2 u pszenicy zwyczajnej.

2. Najmniej specyficznym markerem genu Pm2 jest Whs350, ponieważ pojawił się tylko u 9 spośród 27 testowanych odmian.

3. Odmianami, u których zidentyfikowano gen $P m 2$ przy użyciu trzech markerów $\mathrm{z}$ nim sprzężonych są: Bussard, Sparta, Atomic, Ulka, Tonacja i Lear, można je traktować jako formy referencyjne stanowiące pewne źródło tego genu. 


\section{Literatura / References}

Alam A., Xue F., Wang Ch., Ji W. 2011. Powdery mildew resistance genes in wheat: identyfication and genetic analysis. Journal of Molecural Biology Research 1 (1): 1- 39.

Bennett F.G.A. 1984. Resistance to powdery mildew in wheat: a review of its use in agriculture and breeding programmes. Plant Pathology 33 (3): 279-300.

Czembor H.J., Doraczyńska O., Czembor J.H. 2013. Odporność odmian pszenżyta na mączniaka prawdziwego (Blumeria graminis ff. ssp.) występującego w Polsce. [Resistance of triticale cultivars to powdery mildew (Blumeria graminis ff. ssp.) occurring in Poland.] Biuletyn Instytutu Hodowli i Aklimatyzacji Roślin 267: 3-16.

Duan S., Xu Y., Wu X. 2002. Research progress of pathogen virulence, resistance genes and resistance breeding of wheat powdery mildew (in Chinese). Journal of Triticeae Crops 22: 83-86.

Gao H.L., Zhu F., Jiang Y., Wu J., Yan W., Zhang Q., Jacobi A., Cai S. 2012. Genetic analysis and molecular mapping of a new powdery mildew resistant gene Pm46 in common wheat. Theoretical and Applied Genetics 125 (5): $967-973$.

He R.L., Chang Z.J., Yang Z.J., Yuan Z.Y., Zhan H.X., Zhang X.J., Liu J.X. 2009. Inheritance and mapping of powdery mildew resistance gene Pm43 introgressed from Thinopyrum intermedium into wheat. Theoretical and Applied Genetics 118: 1173-1180.

Huang X.Q., Hsam S.L.K., Zeller F.J. 1997. Identification of powdery mildew resistance genes in common wheat (Triticum aestivum L. em Thell.). IX: cultivars, land races and breeding lines grown in China. Plant Breeding 116: $233-238$.

Klocke B., Flath K., Miedaner T. 2013. Virulence phenotypes in powdery mildew (Blumeria graminis) populations and resistance genes in triticale (x Triticosecale). European Journal of Plant Pathology 137 (3): 463-476.

Liu J., Liu D., Tao W., Li Wu., Wang S., Chen P., Cheng S., Gao D. 2000. Molecular marker-facilitated pyramiding of different genes for powdery mildew resistance in wheat. Plant Breeding 119: 21-24.

Lutz J., Katzhammer M., Stephan U., Felsenstein F., Oppitz K., Zeller F. 1995. Identification of powdery-mildew-resistance genes in common wheat (Triticum aestivum L. em. Thell.). V. Old German cultivars and cultivars released in the former GDR. Plant Breeding 114: 29-33.

Lutz J., Limpert E., Barto P., Zeller F. 1992. Identification of powdery mildew resistance genes in common wheat (Triticum aestivum L.) I. Czechoslovakian Cultivars. Plant Breeding 108: 33-39.

Ma H.Q., Kong Z.X., Fu B.S., Li N., Zhang L.X., Jia H.Y., Ma Z.Q. 2011. Identyfication and mapping of a new powdery mildew resistance gene on chromosome 6D of common wheat. Theoretical Applied Genetics 123: 1099-1106.

Ma P., Xu H., Li L., Zhang H., Han G., Xu Y., Fu X., Zhang X., An D. 2016. Characterization of a new Pm2 allele conferring powdery mildew resistance in the wheat germplasm line FG-1. Frontiers in Plant Science 7: 546.

Ma P.T., Xu H.X., Xu Y.F., Li L.H., Qie Y.M., Luo Q.L. 2015a. Molecular mapping of the new powdery mildew resistance gene Pm2b in Chinese breeding line KM2939. Theoretical Applied Genetics 128: 613-622.

Ma P.T., Xu H.X., Zhang H.X., Li L.H., Xu Y.F., Zhang X.T. 2015b. The gene PmWFJ is a new member of complex Pm2 locus conferring unique powdery mildew resistance in wheat breeding line Wanfengjian 34. Molecular Breeding 35: 210.

Ma P.T., Zhang H.X., Xu H.X., Xu Y.F., Cao Y.W., Zhang X.T., An D. 2015c. The gene PmYB conferes broad-spectrum powdery mildew resistance in the multi-allelic Pm2 chromosome region of the Chinese wheat cultivar YingBo700. Molecular Breeding 35: 124 .

McDonald B.A., Linde C. 2002. Pathogen population genetics, evolutionary potential, and durable resistance. Annual Review of Phytopathology 40: 349-379.

McIntosh R.A., Yamazaki Y., Dubcovsky J., Rogers J., Morris C., Appels R., Xia X.C. 2013. Catalogue of gene symbols for wheat. 12th International Wheat Genetics Symposium. Yokohama, Japan, 8-13 September, 2013, 31 pp.

Miranda L.M., Murphy J.P., Marshall D., Cowger C., Leath S. 2007. Chromosomal location of Pm35 a novel Aegilops tauschii derived powdery mildew resistance gene introgressed into common wheat (Triticum aestivum L.). Theoretical Applied Genetics 114: 1451-1456.

Miranda L.M., Murphy J.P., Marshall D., Leath S. 2006. Pm34: a new powdery mildew resistance gene transferred from Aegilops tauschii to common wheat (Triticum aestivum L.). Theoretical Applied Genetics 113: 1497-1504.

Mwale V.M., Chilembwe E.H.C., Uluko H.C. 2014. Wheat powdery mildew (Blumeria graminis f. sp. tritici): Damage effects and genetic resistance developed in wheat (Triticum aestivum). International Research Journal of Plant Science 5 (1): 1-16.

Niewoehner A.S., Leath S. 1998. Virulence of Blumeria graminis f. sp. tritici on winter wheat in the eastern United States. Plant Disease 82: 64-68.

Niu J.S., Wang B.Q., Wang Y.H., Cao A.Z., Qi Z.J., Shen T.M. 2008. Chromosome location and microsatellite markers linked to a powdery mildew resistance gene in wheat line “Lankao 90(6)”. Plant Breeding 127: 346-349.

Paderina E.V., Hsam S.L.K., Zeller F.J. 1995. Identification of powdery mildew resistance genes in common wheat (Triticum aestivum L. em. Thell.). Hereditas 123: 103-107.

Parks R., Carbone I., Murphy J., Marshall D., Cowger C. 2008. Virulence structure of the eastern US wheat powdery mildew population. Plant Disease 92: 1074-1082.

Persaud R., Lipps P. 1995. Virulence genes and virulence gene frequencies of Blumeria graminis f. sp. tritici in Ohio. Plant Disease 79: 494-499.

Pietrusińska A. 2010. Wykorzystanie markerów molekularnych do wprowadzania genów odporności na rdzę brunatną (Puccinia recondita f. sp. tritici) i mączniaka prawdziwego (Blumeria graminis f. sp. tritici) do pszenicy ozimej. [The use of molecular markers for introduction of leaf rust (Puccinia recondita f. sp. tritici) and powdery mildew (Blumeria graminis f. sp. tritici) resistance genes in winter wheat (Triticum aestivum)]. Biuletyn Instytutu Hodowli i Aklimatyzacji Roślin 256: 33-44.

Sun X., Liu D., Zhang H., Huo N., Zhou R., Jia J. 2006. Identification and mapping of two new genes conferring resistance to powdery mildew from Aegilops tauschii (Coss.) Schmal. Journal of Integrative Plant Biology 48 (10): 1204-1209.

Walker A.S., Bouguennec A., Confais J., Morgant G., Leroux P. 2011. Evidence of host-range expansion from new powdery mildew (Blumeria graminis) infections of triticale (x Triticosecale) in France. Plant Pathology 60 (2): $207-220$. 
Xue S., Zhang Z., Lin F., Kong Z., Cao Y., Li C., Yi H., Mei M., Zhu H., Wu J., Xu H., Zhao D., Tian D., Zhang C., Ma Z. 2008. A high-density intervarietal map of the wheat genome enriched with markers derived from expressed sequence tags. Theoretical Applied Genetics 117: 181-189.

Yao G., Zhang J., Yang L., Xu H., Jiang Y., Xiong L., Zhang C., Zhang Z., Ma Z., Sorrells M. 2007. Genetic mapping of two powdery mildew resistance genes in einkorn (Triticum monococcum L.) accessions. Theoretical Applied Genetics 114: 351-358.

Zhu Z., Zhou R., Kong X., Dong Y., Jia J. 2006. Microsatellite marker identification of a Triticum aestivum-Aegilops umbellulata substitution line with powdery mildew resistance. Euphytica 150: 149-153. 